Bull. Chem. Soc. Ethiop. 2021, 35(2), 449-459.

ISSN 1011-3924

(c) 2021 Chemical Society of Ethiopia and The Authors

Printed in Ethiopia

DOI: https://dx.doi.org/10.4314/bcse.v35i2.17

Online ISSN 1726-801X

\title{
SYNTHESIS OF NOVEL NITROGEN HETEROCYCLES BEARING BIOLOGICAL ACTIVE CARBOXAMIDE MOIETY AS POTENTIAL ANTITUMOR AGENTS
}

\author{
Safyah B. Bakare*
}

Faculty of Education, Shaqra University, Al Muzahimiyah, Shaqra, Riyadh Province, P.O. Box 205, Zip Code 11972, Saudi Arabia

(Received February 1, 2021; Revised October 2, 2021; Accepted October 2, 2021)

\begin{abstract}
In the present study, synthesis of a simple series of nitrogen heterocycles containing $N$-( $p$ bromophenyl) carboxamide moiety, such as benzimidazole, benzoxazine, oxadiazole and triazole compounds, by using 4-bromo aniline and diethyl oxalate as a key starting material has been described. Five nitrogen heterocycles compounds moiety were evaluated for their anticancer activity against MCF-7 cell line. The results revealed that compound 8 ( $N$-(4-bromophenyl)-5-thioxo-1,3,4-oxadiazole-2-carboxamide) was the most potent cytotoxic activity. Cell cycle analysis demonstrated that compound $\mathbf{8}$ induce cell cycle arrest at G1 phase with apoptosis inducing activity marked by increase in G0 phase.
\end{abstract}

KEY WORDS: Synthesis, Nitrogen heterocycles, Carboxamide, Antitumor agents

\section{INTRODUCTION}

The rapid spread of cancer has sparked an intense worldwide search for new nitrogen heterocycles containing carboxamide moiety, which may be used in designing novel antitumor drugs. Among these, tiazofurin (TR, 2- $\beta$-D-furanosylthiazole-4-carboxamide), a natural Cnucleoside, was reported to possess potential anticancer activity (Figure 1) [1]. Furthermore, the antitumor activities of the natural antineoplastic antibiotic bleomycin, netropsin, and thiazole netropsin have been reported [2].
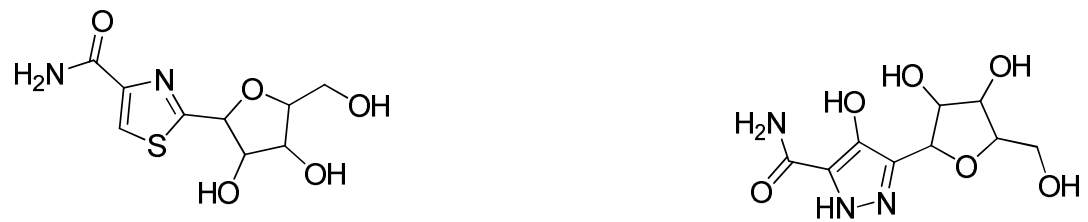

Tiazofurin

Figure 1. Structures of nitrogen heterocycles as antitumor agents.

Benzimidazole nucleus as nitrogen heterocycles is an important pharmacophore in modern drug discovery [3]. Substituted benzimidazole derivatives have found commercial application in veterinarian medicine as anthelmintic agents and used to act as topoisomerase inhibitors [4], selective neuropeptide II receptor antagonists [5], angiotensin II inhibitors [6], potential antitumor agents $[7,8]$, treatment for interstitial cystitis and ulcers $[9,10]$, antimicrobial agents [11], smooth muscle cell proliferation inhibitors [12], and diverse area of chemistry [13]. In addition, benzimidazole is very important intermediate in organic reaction [14]. Benzimidazole derivatives exhibit significant activity against several viruses such as HIV [15], herpes (HSV-1) [16], RNA [17], influenza [18] and human cytomegalovirus (HCMV) [19].

*Corresponding author. E-mail: safyahbakare@gmail.com

This work is licensed under the Creative Commons Attribution 4.0 International License 
Triazole nucleus as nitrogen heterocycles has an attracted wide attention of the medicinal chemists in search for new therapeutic molecules. Literature survey on triazoles has shown that these derivatives possess broad spectrum of biological activities including good P38 map kinase inhibition and anti-inflammatory activity [20-22].

Due to broad spectrum activities reported in the literature [23-28] so far, we have synthesized several nitrogen heterocycles containing carboxamide moiety, targeting for potent molecules possessing antitumor and kinase inhibitory activity [23].

We have described in this paper the synthesis of new nitrogen heterocycles bearing biologically active $N$-(4-bromophenyl) carboxamide moiety by using diethyl oxalate and $p$ bromoaniline as starting material. Some synthesized nitrogen heterocycles were evaluated against cancer cell lines.

\section{EXPERIMENTAL}

\section{Chemistry}

${ }^{1} \mathrm{H}-\mathrm{NMR}$ spectra were recorded using Bruker 400 DRX-Avance NMR spectrometer. Chemical shifts of ${ }^{1} \mathrm{H}$-NMR spectra were reported relative to tetramethyl silane (TMS). ${ }^{13} \mathrm{C}$-NMR spectra were run using a Bruker DRX-Avance NMR spectrometer. The prepared compounds were dissolved in deuterated dimethyl sulfoxide (DMSO) as solvent. Splitting patterns were reported as s, singlet; d, doublet; t, triplet; q, quartet; m, multiplet; br, broad. IR spectra were recorded using a broker FT-8000 spectrometer and frequencies were expressed in $\mathrm{cm}^{-1}$. The molecular weight of the prepared compounds was determined by electron ionization (EI) mass spectrometer operating at $70 \mathrm{eV}$. Melting point of the synthesized compounds was measured with an electrothermal melting point apparatus and has not been corrected. All the prepared compounds give satisfactory elemental analyses within $0.04 \%$ of the theoretical values. The elemental analyses were carried out on a Perkin-Elmer 2400 series CHN. Chemicals and solvents were purchased from commercial sources in analytical grade purity.

Synthesis of ester oxalic acid amide

A mixture of equimolar quantity of diethyl oxalate $(0.01 \mathrm{~mol})$ and 4-bromoaniline $(0.01 \mathrm{~mol})$ in $50 \mathrm{~mL}$ acetic acid was heated under reflux for $2-3 \mathrm{~h}$. The reaction mixture was cooled and poured into ice-water with stirring. The solid product formed was collected after filtration, washed with water, dried, and recrystallized from ethanol to give $\mathbf{1}$.

As colorless crystals, yield 63\%. m.p. $121-123^{\circ} \mathrm{C}$. IR (KBr) $v_{\max }: 3265(\mathrm{NH}), 1753,1705$ $(\mathrm{C}=\mathrm{O}), 1605,1585(\mathrm{C}=\mathrm{C}) \mathrm{cm}^{-1} .{ }^{1} \mathrm{H}-\mathrm{NMR}\left(\mathrm{DMSO}-d_{6}\right) \delta: 1.32\left(\mathrm{t}, 3 \mathrm{H}, \mathrm{CH}_{3}\right), 4.32\left(\mathrm{q}, 2 \mathrm{H}, \mathrm{OCH}_{2}\right)$, $7.58(\mathrm{~d}, 2 \mathrm{H}, \mathrm{Ar}-\mathrm{H}), 7.86(\mathrm{~d}, 2 \mathrm{H}, \mathrm{Ar}-\mathrm{H}), 11.03$ (NHCO) ppm. Anal. calcd. For $\mathrm{C}_{10} \mathrm{H}_{10} \mathrm{BrNO}_{3}$ (271): C, 44.28; H, 3.69; N, 5.17. Found: C, 44.09; H, 3.33; N, 5.01.

Synthesis of 2-substituted aniline (2) and 2-substituted benzoic acid (3)

A mixture of ester oxalic acid amide $1(0.01 \mathrm{~mol})$ and aromatic amine derivatives (namely, $o$ phenylene diamine and anthranilic acid $(0.01 \mathrm{~mol})$ in $50 \mathrm{~mL}$ glacial acetic acid was heated under reflux for 2-3 h, then cooled and poured into water. The resulting solid was filtered off, washed with water and dried. Finally, the product was crystallized from butanol to give $\mathbf{2}$ and $\mathbf{3}$.

2-[(4-Bromophenylamino)-carbonyl, (ethoxy)methylideneamino]aniline (2)

As colorless crystals, yield 71\%. m.p. $240-242{ }^{\circ} \mathrm{C}$. IR (KBr) $v_{\max }: 3231(\mathrm{NH}), 1757,1707$ $(\mathrm{C}=\mathrm{O}), 1603,1595(\mathrm{C}=\mathrm{C}) \mathrm{cm}^{-1} .{ }^{1} \mathrm{H}-\mathrm{NMR}\left(\mathrm{DMSO}-d_{6}\right) \delta: 1.33\left(\mathrm{t}, 3 \mathrm{H}, \mathrm{CH}_{3}\right), 4.32\left(\mathrm{q}, 2 \mathrm{H}, \mathrm{OCH}_{2}\right)$, 7.34-7.96 (m, 10H, Ar-H and $\left.\mathrm{NH}_{2}\right), 10.88,11.04$ and 11.11 (NHCO, N=C-OH) ppm. ${ }^{13} \mathrm{C}-\mathrm{NMR}$ $\left(\mathrm{DMSO}-d_{6}\right) \delta$ : 162.44 (CO of amide), $160.90(\mathrm{O}-\mathrm{C}=\mathrm{N}), 159.01,157.96(\mathrm{~N}=\mathrm{C}-\mathrm{OH}), 145.79$, 
Synthesis of novel nitrogen heterocycles bearing biological active carboxamide moiety

$142.30,138.20,137.70,137.51,137.39,132.11,132.04,132.00,122.91,122.86,122.60$, 122.57, 117.09, 116.73, 116.41, 115.70 (C-aromatic), $62.98\left(\mathrm{OCH}_{2}\right), 14.32\left(\mathrm{CH}_{3}\right) \mathrm{ppm} . \mathrm{MS}: \mathrm{m} / \mathrm{z}$ $(\%)=361\left(\mathrm{M}^{+}\right)$. Anal. calcd. For $\mathrm{C}_{16} \mathrm{H}_{16} \mathrm{BrN}_{3} \mathrm{O}_{2}$ (361): C, 53.18; H, 4.43; N, 11.63. Found: $\mathrm{C}$, 53.36; H, 4.56; N, 11.52 .

\section{2-[(1-Ethoxy-2-oxo-2-(phenylamino)ethylideneamino]benzoic acid (3)}

As yellow crystals, yield 69\%. m.p. $215-217^{\circ} \mathrm{C}$. IR (KBr) v $v_{\max }: 2930-3271$ (br. OH), $3261(\mathrm{NH})$, 1749, $1701(\mathrm{C}=\mathrm{O}), 1603,1587(\mathrm{C}=\mathrm{C}) \mathrm{cm}^{-1} .{ }^{1} \mathrm{H}-\mathrm{NMR}\left(\mathrm{DMSO}-d_{6}\right) \delta: 1.30\left(\mathrm{t}, 3 \mathrm{H}, \mathrm{CH}_{3}\right), 4.29(\mathrm{q}$, $\left.2 \mathrm{H}, \mathrm{OCH}_{2}\right), 7.21-8.02(\mathrm{~m}, 7 \mathrm{H}, \mathrm{Ar}-\mathrm{H}), 8.61(\mathrm{~d}, 1 \mathrm{H}, \mathrm{Ar}-\mathrm{H}), 10.86,10.95$ and $11.02(\mathrm{NHCO}$ and $\mathrm{N}=\mathrm{C}-\mathrm{OH}), 12.76(\mathrm{~s}, 1 \mathrm{H}, \mathrm{COOH}) \mathrm{ppm}$. Anal. calcd. For $\mathrm{C}_{17} \mathrm{H}_{15} \mathrm{BrN}_{2} \mathrm{O}_{4}(390)$ : C, 52.31; H, 3.85; N, 7.18. Found: C, 52.18; H, 3.67; N, 7.07.

Synthesis of N-(4-bromophenyl)-benzimidazole-2-carboxamide (4) and N-(4-bromophenyl)-3,1benzoxazine-2-carboxamide (5)

A solution of compounds 2 and $3(0.01 \mathrm{~mol})$ in acetic anhydride $(20 \mathrm{~mL})$ was heated under reflux for $2 \mathrm{~h}$, then cooled and poured into ice-water. The reaction mixture was left for $24 \mathrm{~h}$ and the solid formed was filtered off, washed with water, and dried. Finally, the product was crystallized from ethanol to give $\mathbf{4}$ and $\mathbf{5}$.

Compound 4 as colorless crystals, yield 63\%. m.p. $260-262{ }^{\circ} \mathrm{C}$. IR $(\mathrm{KBr}) \mathrm{v}_{\max }: 3232(\mathrm{NH})$, 1752, $1691(\mathrm{C}=\mathrm{O}), 1604,1587(\mathrm{C}=\mathrm{C}) \mathrm{cm}^{-1} .{ }^{1} \mathrm{H}-\mathrm{NMR}\left(\mathrm{DMSO}-d_{6}\right) \delta:$ 7.23-7.87 (m, 8H, Ar-H), 10.95 and $11.02(\mathrm{NHCO}$ and $\mathrm{N}=\mathrm{C}-\mathrm{OH}), 13.41(\mathrm{~s}, 1 \mathrm{H}, \mathrm{NH}) \mathrm{ppm} .{ }^{13} \mathrm{C}-\mathrm{NMR}$ (DMSO- $\left.d_{6}\right) \delta$ : $159.01(\mathrm{NHCO}), 157.96(\mathrm{~N}=\mathrm{C}-\mathrm{OH}), 145.79(\mathrm{C}=\mathrm{N}), 142.95(\mathrm{C}-\mathrm{N}), 138.20,137.51,135.21$, $133.03,132.11,132.00,125.65,125.04,123.32,122.91,122.86,120.98,120.55,117.09$, 116.41, 113.18 (C-aromatic) ppm. MS: $\mathrm{m} / \mathrm{z}(\%)=315\left(\mathrm{M}^{+}\right)$. Anal. calcd. For $\mathrm{C}_{14} \mathrm{H}_{10} \mathrm{BrN}_{3} \mathrm{O}$ (315): C, 53.33; H, 3.17; N, 13.33. Found: C, 53.11; H, 3.02; N, 13.17.

Compound 5 as colorless crystals, yield 61\%. m.p. $239-241{ }^{\circ} \mathrm{C}$. IR $(\mathrm{KBr}) \mathrm{v}_{\max }: 3229(\mathrm{NH})$, 1757, $1693(\mathrm{C}=\mathrm{O}), 1600,1583(\mathrm{C}=\mathrm{C}) \mathrm{cm}^{-1} .{ }^{1} \mathrm{H}-\mathrm{NMR}\left(\mathrm{DMSO}-d_{6}\right) \delta: 7.49-8.16(\mathrm{~m}, 8 \mathrm{H}, \mathrm{Ar}-\mathrm{H})$, 10.92 and 10.95 ( NHCO and $\mathrm{N}=\mathrm{C}-\mathrm{OH}) \mathrm{ppm} .{ }^{13} \mathrm{C}-\mathrm{NMR}$ (DMSO- $d_{6}$ ) $\delta: 159.00(\mathrm{NCO}), 158.80$ $(\mathrm{O}-\mathrm{C}=\mathrm{O}), 156.22(\mathrm{~N}=\mathrm{C}-\mathrm{OH}), 150.08(\mathrm{~N}=\mathrm{C}-\mathrm{O}), 144.99,137.62,137.57,137.51,137.39,132.63$, $132.11,130.86,130.38,128.82,128.01,127.84,123.17,123.01,122.91,118.56,117.09,117.06$ ppm. MS: $\mathrm{m} / \mathrm{z}(\%)=345\left(\mathrm{M}^{+}\right)$. Anal. calcd. For $\mathrm{C}_{15} \mathrm{H}_{9} \mathrm{BrN}_{2} \mathrm{O}_{3}(345): \mathrm{C}, 52.20 ; \mathrm{H}, 2.63 ; \mathrm{N}, 8.12$. Found: C, 52.01; H, 2.52; N, 8.19.

Synthesis of N-(4-bromophenyl)-3-(ethoxycarbonyl)methyl benzimidazole-2-carboxamide (6).

A mixture of benzimidazole-2-carboxamide $4(0.01 \mathrm{~mol})$ and ethyl chloro acetate $(0.01 \mathrm{~mol})$ in dimethyl formamide $(30 \mathrm{~mL})$ was heated under reflux for $6 \mathrm{~h}$, then cooled and poured into water. The reaction mixture was neutralized with dilute hydrochloric acid $(1 \mathrm{M})$. The solid obtained was filtered off, washed with water, dried and purified by recrystallization from ethanol to give compound $\mathbf{6}$.

As pale-yellow crystals, yield 61\%. m.p. $190-192{ }^{\circ} \mathrm{C}$. IR (KBr) $v_{\max }: 3287(\mathrm{NH}), 1772,1678$ $(\mathrm{C}=\mathrm{O}), 1632(\mathrm{C}=\mathrm{N}), 1610,1592(\mathrm{C}=\mathrm{C}), 1425\left(\mathrm{CH}_{2}\right), 1171,1098(\mathrm{C}-\mathrm{O}) \mathrm{cm}^{-1} .{ }^{1} \mathrm{H}-\mathrm{NMR}$ (DMSO$\left.d_{6}\right) \delta: 1.22\left(\mathrm{t}, 3 \mathrm{H}, \mathrm{CH}_{3}\right), 4.18\left(\mathrm{q}, 2 \mathrm{H}, \mathrm{OCH}_{2}\right), 5.55\left(\mathrm{~s}, 2 \mathrm{H}, \mathrm{NCH}_{2} \mathrm{CO}\right), 7.41-7.95(\mathrm{~m}, 8 \mathrm{~h}, \mathrm{Ar}-\mathrm{H})$, 11.04 and $11.15(\mathrm{NHCO}$ and $\mathrm{N}=\mathrm{C}-\mathrm{OH}) \mathrm{ppm} .{ }^{13} \mathrm{C}-\mathrm{NMR}\left(\mathrm{DMSO}-d_{6}\right) \delta: 168.79,158.28(\mathrm{C}=\mathrm{O}$ of ester and amide), $143.72(\mathrm{~N}=\mathrm{C}-\mathrm{O}), 140.63(\mathrm{~N}-\mathrm{C}=\mathrm{N}), 137.79,137.31,137.01,132.11,132.01$, 125.52, 124.16, 123.01, 120.85, 117.19, 116.66, 111.78, (C-aromatic), 61.73, $\left(\mathrm{OCH}_{2}\right), 47.00$ $\left(\mathrm{NCH}_{2} \mathrm{CO}\right), 14.45\left(\mathrm{CH}_{3}\right)$ ppm. Anal. calcd. For $\mathrm{C}_{18} \mathrm{H}_{16} \mathrm{BrN}_{3} \mathrm{O}_{2}(385)$ : C, 56.10; H, 4.16; N, 10.91. Found: C, 55.98; H, 4.02; N, 10.66. 
Synthesis of $N$-(amino), $N$-(4-bromophenyl)oxalic acid dicarboxamides (7)

Reaction of ester oxalic acid carboxamide $1(0.01 \mathrm{~mol})$ with hydrazine hydrate $(0.01 \mathrm{~mol})$ in ethanol $(30 \mathrm{~mL})$ was heated under reflux for $2 \mathrm{~h}$, the reaction mixture was cooled and poured into water, then neutralized with dilute hydrochloric acid (1\%). Solid product formed was filtered off, washed with water, dried and recrystallized from ethanol to give 7.

As pale-yellow crystals, yield $56 \%$. m.p. $225-227^{\circ} \mathrm{C}$. IR $(\mathrm{KBr}) v_{\max }: 3356,3285\left(\mathrm{NH}_{2}\right.$ and $\mathrm{NH}) 1689(\mathrm{C}=\mathrm{O}), 1605,1592(\mathrm{C}=\mathrm{C}) \mathrm{cm}^{-1} .{ }^{1} \mathrm{H}-\mathrm{NMR}\left(\mathrm{DMSO}-d_{6}\right) \delta: 5.21\left(\mathrm{~s}, 2 \mathrm{H}, \mathrm{NH}_{2}\right), 7.57(\mathrm{~d}$, $2 \mathrm{H}, \mathrm{Ar}-\mathrm{H}), 7.87(\mathrm{~d}, 2 \mathrm{H}, \mathrm{Ar}-\mathrm{H}), 10.51(\mathrm{~s}, 1 \mathrm{H}, \mathrm{NH}), 11.02,11.17$ (NHCO, N=C-OH) ppm. Anal. calcd. For $\mathrm{C}_{8} \mathrm{H}_{8} \mathrm{BrN}_{3} \mathrm{O}_{2}$ (257): C, 37.35; H, 3.11; N, 16.34. Found: C, 37.37; H, 3.02; N, 16.26.

Synthesis of N-(4-bromophenyl)-5-thioxo-1,3,4-oxadiazole-2-carboxamide (8)

A mixture of compound $7(0.01 \mathrm{~mol})$ and carbon disulphide $(0.02 \mathrm{~mol})$ was refluxed in pyridine $(30 \mathrm{~mL})$ for $8 \mathrm{~h}$. The reaction mixture was cooled and poured into ice-water, then neutralized with dilute hydrochloric acid $(1 \mathrm{M})$. The formed product was filtered off, washed with water, dried, and recrystallized from ethanol to give $\mathbf{8}$.

As colorless crystals, yield 62\%. m.p. $263-265^{\circ} \mathrm{C}$. IR ( $\left.\mathrm{KBr}\right) v_{\max }: 3281(\mathrm{NH}), 1687(\mathrm{C}=\mathrm{O})$, $1601,1590(\mathrm{C}=\mathrm{C}) \mathrm{cm}^{-1} .{ }^{1} \mathrm{H}-\mathrm{NMR}\left(\mathrm{DMSO}-d_{6}\right) \delta: 7.51-7.60(\mathrm{~d}, 2 \mathrm{H}, \mathrm{Ar}-\mathrm{H}), 7.80-7.86(\mathrm{~d}, 2 \mathrm{H}, \mathrm{Ar}-$ $\mathrm{H}$ ), 10.87 AND 11.03 ( NHCO and $\mathrm{N}=\mathrm{C}-\mathrm{OH}), 11.14(\mathrm{~s}, 1 \mathrm{H}, \mathrm{NH}) \mathrm{ppm} .{ }^{13} \mathrm{C}-\mathrm{NMR}\left(\mathrm{DMSO}-d_{6}\right) \delta$ : $178.62(\mathrm{C}=\mathrm{S}), 159.84(\mathrm{CONH}), 154.84(\mathrm{~N}=\mathrm{C}-\mathrm{OH}) 150.97(\mathrm{~N}=\mathrm{C}-\mathrm{O}), 137.51,137.34,132.16$, 132.11, 132.06, 123.17, 122.97, 122.91, 117.28, 117.09 (C-aromatic) ppm. MS: m/z (\%) = 299 $\left(\mathrm{M}^{+}\right)$. Anal. calcd. For $\mathrm{C}_{9} \mathrm{H}_{6} \mathrm{BrN}_{3} \mathrm{O}_{2}$ (299): C, 36.12; H, 2.01; N, 14.05. Found: $\mathrm{C}, 36.08 ; \mathrm{H}$, $1.92 ; \mathrm{N}, 13.88$.

Synthesis of N-(4-bromophenyl)-5-thioxo-4-amino-1,2,4-triazole-3-carboxamide (9)

A mixture of $N$-(4-bromophenyl)-5-thioxo-1,3,4-oxadiazole-2-carboxamide (8) $(0.01 \mathrm{~mol})$ and hydrazine hydrate $(2 \mathrm{~mL})$ in absolute ethanol was heated under reflux for $4 \mathrm{~h}$. the solvent and excess of hydrazine hydrate were removed under reduced pressure. The residue washed with ether and recrystallized from ethanol to give $\mathbf{9}$.

As pale-yellow crystals, yield $63 \%$. m.p. $263-265{ }^{\circ} \mathrm{C}$. IR $(\mathrm{KBr}) v_{\max }: 3388,3261,3199\left(\mathrm{NH}_{2}\right.$ and $\mathrm{NH}) 1691(\mathrm{C}=\mathrm{O}), 1589,1583(\mathrm{C}=\mathrm{C}) \mathrm{cm}^{-1} .{ }^{1} \mathrm{H}-\mathrm{NMR}\left(\mathrm{DMSO}-d_{6}\right) \delta: 6.10\left(\mathrm{~s}, 2 \mathrm{H}, \mathrm{NH}_{2}\right), 7.52-$ $7.80(\mathrm{~m}, 4 \mathrm{H}, \mathrm{Ar}-\mathrm{H}), 10.34$ (s, 1H, NH), 10.78 (s, 1H, SH), 11.09, 11.15 (s, 1H, NHCO and $\mathrm{N}=\mathrm{C}-\mathrm{OH}) \mathrm{ppm} .{ }^{13} \mathrm{C}-\mathrm{NMR}\left(\mathrm{DMSO}-d_{6}\right) \delta: 166.50(\mathrm{C}=\mathrm{S}), 159.90(\mathrm{CONH}), 158.18(\mathrm{~N}=\mathrm{C}-\mathrm{OH})$ $154.18(\mathrm{~N}=\mathrm{C}-\mathrm{N}), 143.54(\mathrm{~N}=\mathrm{C}-\mathrm{SH}), 137.59,137.51,137.42,132.30,132.11,131.99,122.91$, 122.77, 122.60, 117.09, 116.98, 116.75 (C-aromatic) ppm. MS: m/z (\%) = $313\left(\mathrm{M}^{+}\right)$. Anal. calcd. For $\mathrm{C}_{9} \mathrm{H}_{8} \mathrm{BrN}_{5} \mathrm{OS}$ (313): C, 34.50; H, 2.56; N, 22.36. Found: C, 34.33; H, 2.42; N, 22.16.

Anti-tumor activity against breast cancer cell line (MCF-7)

The cytotoxic activity was measured in vitro for the thiohydantoin derivatives using the MTT assay. Cells were plated in 96 - multiwall plate $\left(10^{5}\right.$ cells/well $)$ for $24 \mathrm{~h}$ before treatment with the compounds. Test compounds were dissolved in dimethyl sulfoxide. Different concentrations of the compound under test $(10,25,50$, and $100 \mu \mathrm{M})$ were added to the cell's monolayer. Triplicate wells were prepared for each individual concentration. Monolayer cells were incubated with the compound(s) for $48 \mathrm{~h}$ at $37{ }^{\circ} \mathrm{C}$ and in atmosphere of $5 \% \mathrm{CO}_{2}$. After $48 \mathrm{~h}$, cells were fixed, washed, and stained with $40 \mu \mathrm{L}$ of MTT solution $(5 \mathrm{mg} / \mathrm{mL}$ of MTT in $0.9 \% \mathrm{NaCl})$ in each well was added and incubated for an additional $4 \mathrm{~h}$. MTT crystals were solubilized by adding $180 \mu \mathrm{L}$ of acidified isopropanol/well and the plate was shaken at room temperature, followed by photometric determination of the absorbance at $570 \mathrm{~nm}$ using ELISA reader. The molar 
concentration required to inhibit $50 \%$ of cell viability $\left(\mathrm{IC}_{50}\right)$ was calculated and compared with the reference drug doxorubicin. The surviving fractions were expressed as means \pm S.E.M.

\section{Cell cycle analysis of compound $\boldsymbol{8}$}

MCF-7 cells, $\left(3.0 \times 10^{5}\right.$ cells/well) and incubated at $37{ }^{\circ} \mathrm{C}$ for $12 \mathrm{~h}$. The target cells were then treated with the compound 8 at its $\mathrm{IC}_{50}$ concentration dose value for $48 \mathrm{~h}$. After treatment, cells were collected and fixed with $75 \%$ ethanol at $20{ }^{\circ} \mathrm{C}$ overnight, then, cells were washed with PBS followed by centrifugation and incubated with $(10 \mathrm{mg} / \mathrm{mL})$ Rnase (Sigma, USA) and $(5 \mathrm{mg} / \mathrm{mL})$ propidium iodide (PI, Sigma) before flow cytometry analysis (FACSCalibur cytometer using Cell quest software, BD Bioscience, USA).

Apoptosis determination by Annexin-Vassay

The MCF-7 cells, $\left(2 \times 10^{5}\right.$ cells/well $)$ were treated with compound $\mathbf{8}$ at its $\mathrm{IC}_{50}$ concentration value for $48 \mathrm{~h}$. After treatment, cells were harvested and washed twice $\left(180 \mathrm{~g}, 10 \mathrm{~min}, 4{ }^{\circ} \mathrm{C}\right)$ with PBS. Each cell well was resuspended in $100 \mu \mathrm{L}$ of binding buffer, and $5 \mu \mathrm{L}$ Annexin VFITC were added. After an incubation time of $10 \mathrm{~min}$ at room temperature, additional $400 \mu \mathrm{L}$ of binding buffer were added for a final volume of $500 \mu \mathrm{L}$. Cells were stained with PI immediately before measurement. Cells were the analyzed by using FACSCalibur Flow cytometer (Becton and Dickinson, Heidelberg, Germany). Data thus obtained were analyzed with Cell-Quest software (Becton and Dickinson, Heidelberg, Germany).

\section{RESULTS AND DISCUSSION}

\section{Chemistry}

In this investigation, a new simple series of nitrogen heterocycles containing $N$-(4-bromophenyl) carboxamide moiety were designed, synthesized (Scheme 1) and biologically evaluated for their invitro antitumor activity.

Thus, reaction of diethyl oxalate with $p$-bromoaniline in acetic acid under reflux gave the corresponding ester oxalic acid amide (1) as a key starting material. Condensation of ester oxalic acid amide (1) with $o$-phenylene diamine and anthranilic acid in glacial acetic acid led to the formation of 2-[(4-bromophenylamino)-carbonyl, (ethoxy)methylideneamino]aniline (2) and 2-[(1-ethoxy-2-oxo-2-(phenylamino)ethylideneamino]benzoic acid (3), respectively.

$N$-(4-bromophenyl)-benzimidazole-2-carboxamide (4) and $N$-(4-bromophenyl)-3,1-benzoxazine-2-carboxamide (5) were obtained via cyclization of 2-substituted aniline (2) and 2substituted benzoic acid (3) with acetic anhydride under reflux. Alkylation of benzimidazole-2carboxamide derivative (4) with ethyl chloroacetate in dimethyl formamide to yield $\mathrm{N}$-(4bromophenyl)-3-(ethoxycarbonyl)methyl benzimidazole-2-carboxamide (6).

Condensation of ester derivative (1) with hydrazine hydrate in ethanol under reflux led to the formation ofoxalic acid hydrazide derivative (7). The compound 7 was reacted with carbon disulphide in pyridine under reflux gave the corresponding $N$-(4-bromophenyl)-5-thioxo-1,3,4oxadiazole-2-carboxamide (8).

Treatment of 1,3,4-oxadiazole derivative (8) with hydrazine hydrate in ethanol under reflux afforded the corresponding $N$-(4-bromophenyl)-5-thioxo-4-amino-1,2,4-triazole-3-carboxamide (9).

NMR spectra investigation of synthesized nitrogen heterocycles (4-9)

To confirm the struct6ural features of the compounds, ${ }^{1} \mathrm{H}-\mathrm{NMR}$ and ${ }^{13} \mathrm{C}-\mathrm{NMR}$ spectra of the synthesized nitrogen heterocycles (4-9), recorded in DMSO- $d_{6}$ were examined. 
${ }^{1} H$-NMR spectra investigation of nitrogen heterocycles (4-9)

Compounds 4, 5 and 6

From the data of ${ }^{1} \mathrm{H}-\mathrm{NMR}$ spectra for the compounds $\mathbf{4}$ and $\mathbf{5}$ gave clear cut evidence singlet signals at $\delta 10.95,11.02,13.41 \mathrm{ppm}$ and $\delta 10.92,10.95 \mathrm{ppm}$ due to the proton of $\mathrm{NH}$ function for the carboxamide group for the compounds $\mathbf{4}$ and $\mathbf{5}$.

Also, compounds $\mathbf{4}$ and $\mathbf{5}$ containing the same protons of aromatic rings, which appeared in the ${ }^{1} \mathrm{H}-\mathrm{NMR}$ spectra as multiplet signals in the expected region at $\delta 7.23-8.16$, among total 8 protons for the aromatic rings.

In case of compound $6,{ }^{1} \mathrm{H}-\mathrm{NMR}$ spectrum gave a new three signals at $\delta 5.55$ as singlet, $\delta$ 4.20 as quartet signal and $\delta 1.22 \mathrm{ppm}$ as triplet signal assigned to the protons of methylene and ethoxy function for the $\mathrm{CH}_{2} \mathrm{COOEt}$ group, clearly confirmed the formation of compound $\mathbf{6}$. Also, compound $\mathbf{6}$ containing the same protons of carboxamide and aromatic rings appeared in the ${ }^{1} \mathrm{H}-\mathrm{NMR}$ spectrum at $\delta 11.15,11.04 \mathrm{ppm}(\mathrm{CONH})$ and $\delta 7.40-7.95 \mathrm{ppm}$ as multiplet signals for the aromatic rings.

${ }^{1} \mathrm{H}-\mathrm{NMR}$ spectra of these compounds 4, 5 and $\mathbf{6}$ gives number of proton signals, which showed that the presented two isomer of these compounds as shown in Figure 2.

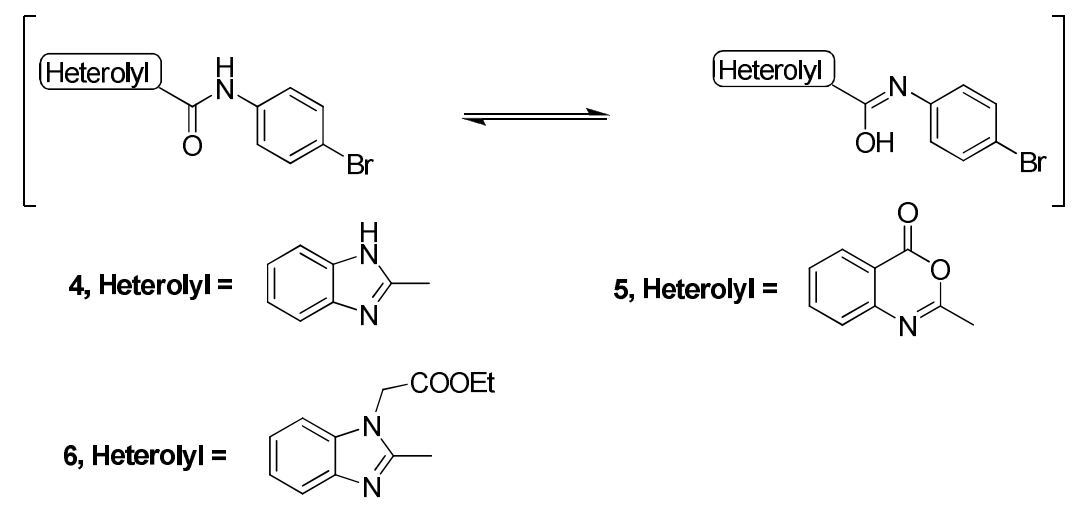

Figure 2. Keto-enol tautomers of compounds 4-6.

\section{Compounds $\boldsymbol{8}$ and $\boldsymbol{9}$}

From study, the ${ }^{1} \mathrm{H}-\mathrm{NMR}$ spectra of compounds 8 and $\mathbf{9}$ showed the structure of these compounds in thione-thiol and keto-enol tautomers. ${ }^{1} \mathrm{H}-\mathrm{NMR}$ spectra of these compounds $\mathbf{8}$ and 9 showed the presented singlet signals in the region at $\delta 10.34-11.20 \mathrm{ppm}$ refer to the protons of carboxamide ( $\mathrm{NHCO}$ and $\mathrm{N}=\mathrm{C}-\mathrm{OH}$ ) and thiosemicarbazide groups. In addition, the number of proton signals of the aromatic ring were observed within the expected chemical shift regions and showed that the presented four isomers of these compounds as shown in Figure 3.

${ }^{13}$ C-NMR spectra investigation of nitrogen heterocycles (4-9)

\section{Compounds 4, 5 and 6}

From study, the ${ }^{13} \mathrm{C}$-NMR spectra of compounds 4,5 and $\mathbf{6}$ showed the structure of these compounds in two isomers as keto-enol tautomers (Figure 2). 
${ }^{13} \mathrm{C}$-NMR spectra of these compounds $\mathbf{4 , 5}$ and $\mathbf{6}$ showed that the presented two characteristic signals at $\delta 159.01,159.00 \mathrm{ppm}$ refer to the protons of NHCO groups for the keto form, and at $\delta 157.96,156.22 \mathrm{ppm}$ attributed to the protons of $\mathrm{OH}(\mathrm{N}=\mathrm{C}-\mathrm{OH})$ groups for the enol form. Also, ${ }^{13} \mathrm{C}-\mathrm{NMR}$ revealed a characteristic carbon signal in the region $\delta 145.00-112.00$ ppm due to the carbons of aromatic ring, these signals further supported the formation of two isomers for these compounds $\mathbf{4 , 5}$ and $\mathbf{6}$.

$$
\square
$$<smiles></smiles>

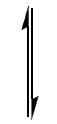<smiles>[X]c1n[nH]c(=S)n1/C(O)=N/c1ccc(Br)cc1</smiles>

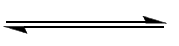<smiles>[X]c1nnc(C(=O)Nc2ccc(Br)cc2)[nH]1</smiles><smiles>I[I-]</smiles>

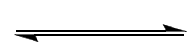<smiles>[X]c1nnc(CC)s1</smiles>

$8, x=0$

9, $\mathrm{X}=\mathrm{N}-\mathrm{NH}_{2}$

Figure 3. Different isomers of compounds 8 and 9.

\section{Compounds $\boldsymbol{8}$ and $\boldsymbol{9}$}

From the data of ${ }^{13} \mathrm{C}-\mathrm{NMR}$ spectra for the compounds 8 and $\mathbf{9}$ gave and showed that the presented characteristic carbon signals in the region $\delta 179.00-142.00 \mathrm{ppm}$ due to the carbons of two isomers for the carboxamide and thiocarboxamide groups as shown in Figure 3 . The ${ }^{13} \mathrm{C}$ NMR spectra of compounds $\mathbf{8}$ and $\mathbf{9}$ showed the presence of three values of each carbon signal of the aromatic ring carbon, these signals further confirmed the presented three isomers of these compounds.

\section{Anti-tumor activity against breast carcinoma (MCF-7) cells}

Compounds 4, 5, 6, 8 and 9 were tested for their anti-proliferative activity against breast carcinoma (MCF-7) cell line using MTT assay method. Doxorubicin (Dox) was employed as positive reference. The $\mathrm{IC}_{50}$ values $(\mu \mathrm{M})$ of the tested compounds and reference compound are listed in Table 1 and presented graphically in Figure 4. The most potent compound $\mathbf{8}$ was the most active with $\mathrm{IC}_{50}$ values less than $5 \mu \mathrm{M}$. In conclusion, compounds 8 and 9 were the most potent active compounds. The highest cytotoxic compound is $\mathbf{8}$ which had $\mathrm{IC}_{50}$ value of 3.81 $\mu \mathrm{M}$ compared with the value of $2.29 \mu \mathrm{M}$ of Dox.

Table 1. Calculated $\mathrm{IC}_{50}(\mu \mathrm{M})$ for compounds $\mathbf{4 , 5 , 6 , 8}$ and 9 against breast carcinoma (MCF-7) cells.

\begin{tabular}{|c|c|c|}
\hline Compound No. & $\mathrm{IC}_{50}(\mu \mathrm{M}) / \mathrm{MCF}-7$ & $\mathrm{IC}_{50}(\mu \mathrm{M}) / \mathrm{Hs} 371 \mathrm{~T}$ \\
\hline $\mathbf{4}$ & $10.01 \pm 0.08$ & - \\
\hline $\mathbf{5}$ & $11.22 \pm 0.61$ & - \\
\hline $\mathbf{6}$ & $29.27 \pm 0.19$ & $75.21 \pm 0.21$ \\
\hline $\mathbf{8}$ & $3.81 \pm 0.11$ & - \\
\hline $\mathbf{9}$ & $5.32 \pm 0.14$ & $112.06 \pm 0.12$ \\
\hline Dox & $2.29 \pm 0.09$ & \\
\hline
\end{tabular}

Bull. Chem. Soc. Ethiop. 2021, 35(2) 
<smiles>CCOC(=Nc1ccccc1N)C(=O)Nc1ccc(Br)cc1</smiles><smiles>CCOC(=O)C(=O)Nc1ccc(Br)cc1</smiles><smiles>NNC(=O)C(=O)Nc1ccc(Br)cc1</smiles>

(2)

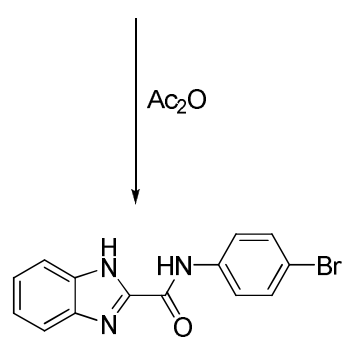

(4)

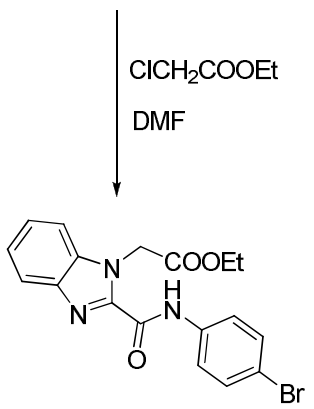

(6)<smiles>CCOC(=Nc1ccccc1C(=O)O)C(=O)Nc1ccc(Br)cc1</smiles>

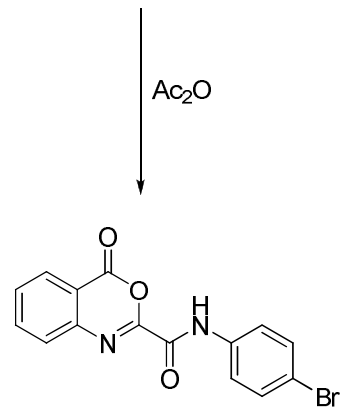

(5)<smiles>Nc1ccccc1C(=O)O</smiles><smiles>O=C(Nc1ccc(Br)cc1)c1n[nH]c(=S)o1</smiles>

(8)<smiles>Nn1c(C(=O)Nc2ccc(Br)cc2)n[nH]c1=S</smiles>

(9)

Scheme 1. Synthesis of nitrogen heterocycles containing $N$-4-(bromophenyl)-carboxamide moiety (4-9).

\section{Cell cycle analysis of compound $\boldsymbol{8}$}

To study the mechanism of anticancer activity of compound $\mathbf{8}$, cell cycle analysis was carried out using DNA flow cytometry analysis in MCF-7 cells. MCF-7 cells were incubated with $\mathrm{IC}_{50}$ concentration of compound $\mathbf{8}$ for $24 \mathrm{~h}$ and then subjected to DNA flow cytometry analysis. Compound 8 could enhance the G1 phase by $13.13 \%$ compared with the untreated control. This effect was accompanied by increase in cell percentage in $\mathrm{G}_{0}$ phase of the cell cycle. These results suggested that compound $\mathbf{8}$ induce cancer cell death via G1 phase arrest with apoptosis inducing activity marked by the presence $\mathrm{G}_{0}$ peak in the cell cycle distribution profile of MCF-7 cells (Figure 5). 


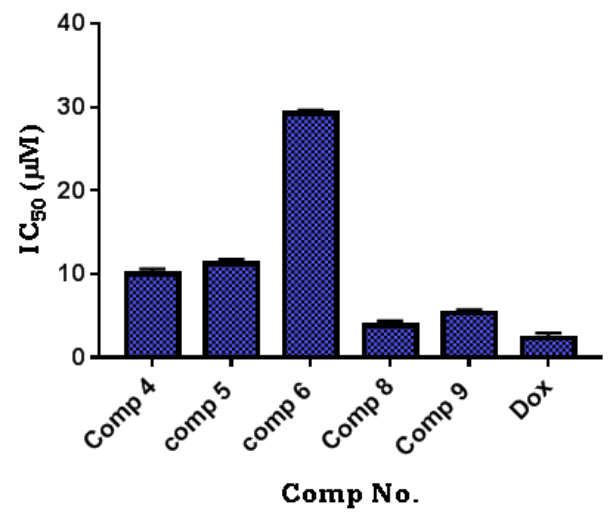

Figure 4. Calculated $\mathrm{IC}_{50}(\mu \mathrm{M})$ for compounds 4, 5, 6, 8 and 9 against breast carcinoma (MCF7) cells.
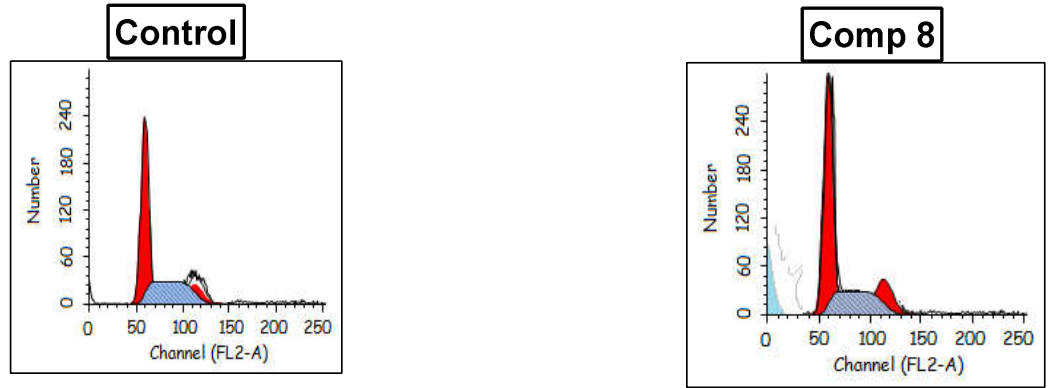

Figure 5. Effect of compound $\mathbf{8}$ on the cell cycle profile of MCF-7.

\section{CONCLUSION}

A new simple series of nitrogen heterocycles bearing biologically active carboxamide moiety were synthesized from $p$-bromo aniline and diethyl oxalate as a key starting material. The structure of these nitrogen heterocycles was confirmed by IR, ${ }^{1} \mathrm{H}-\mathrm{NMR},{ }^{13} \mathrm{C}-\mathrm{NMR}$, MS and elemental analysis. In this work, the synthesized nitrogen heterocycles were screened for their anticancer activity against MCF-7 cells. The results of revealed that compound $\mathbf{8}$ was the most potent cytotoxic activity. Cell cycle analysis demonstrated that compound $\mathbf{8}$ induce cell cycle arrest at G1 phase with apoptosis inducing activity marked by increase in G0 phase.

\section{REFERENCES}

1. Fujita, S.; Yamamoto, S.; Akasu, T.; Moriya, Y.; Taniguchi, H.; Shimoda, T. Quantification of CD10 mRNA in colorectal cancer and relationship between mRNA expression and liver metastasis. Anticancer Res. 2007, 27, 3307-3312.

2. Silverman, R.B. The Organic Chemistry of Drug Design and Drug Action, Academic Press: London; 1992; p 263. 
3. Tebbe, M.J.; Spitzer, W.A.; Victor, F.; Miller, S.C.; Lee, C.C.; Sattelbery, T.R.; Mckinney, E.; Tang, C.S. Antirhino/enteroviral vinylacetylene benzimidazoles: A study of their activity and oral plasma levels in mice. J. Med. Chem. 1997, 40, 3937-3946.

4. Kim, J.S.; Cratto, B.; Yu, C.; Liu, A.; Liu, L.F.; Lavioe, E. Substituted 2,5'-Bi-1Hbenzimidazoles: Topoisomerase I inhibition and cytotoxicity. J. Med. Chem. 1996, 39, 992998.

5. Zarrinmayeh, H.; Zimmerman, D.M.; Cantrell, B.E.; Schober, D.A.; Bruns, R.F. Structureactivity relationship of a series of diaminoalkyl substituted benzimidazole as neuropeptide $\mathrm{Y}$ Y1 receptor antagonists. Bioorg. Med. Chem. Lett. 1999, 9, 647-652.

6. Kohara, Y.; Kubo, K.; Imamiya, E.; Wada, T.; Inada, Y.; Naka, T. Synthesis and angiotensin II receptor antagonistic activities of benzimidazole derivatives bearing acidic heterocycles as novel tetrazole bioisosteres. J. Med. Chem. 1996, 39, 5228-5235.

7. Denny, W.A.; Rewcastle, O.W.; Bagley, B.C. Potential antitumor agents. 59. Structureactivity relationships for 2-phenylbenzimidazole-4-carboxamides, a new class of minimal DNA-intercalating agents which may not act via topoisomerase II. J. Med. Chem. 1990, 33 , 814-819.

8. White, W.A.; Curtin, J.N.; Eastman, W.B.; Golding, T.B.; Hostomsky, Z.; Kyle, S.; Li, J.; Maegley, A.K.; Skalitzky, J.D.; Webber, E.S.; Yu, X.H.; Griffin, J.R. Potentiation of cytotoxic drug activity in human tumour cell lines, by amine-substituted 2arylbenzimidazole-4-carboxamide PARP-1 inhibitors. Bioorg. Med. Chem. Lett. 2004, 14, 2433-2437.

9. Lyenger, S.; Nuhhauser, M.A.; Thor, K.B. US Patent 1996, 13, 129.

10. Spasov, A.A.; Pozhitsa, N.I.; Bugaeva, I.L.; Anisimova, A.V. Benzimidazole derivatives: Spectrum of pharmacological activity and toxicological properties (a review). Pharm. Chem. J. 1999, 33, 232-243.

11. Kazimier, Z.; Andrzejewska, M.; Kaustova, J.; Klimesova, V. Synthesis and antimycobacterial activity of 2-substituted halogenobenzimidazoles. Eur. J. Med. Chem. 2005, 40, 203-208.

12. Elokdah, H.M.; Chai, S.Y.; Sulkowski, T.S. US Patent 1998, 5, 764, 473; Chem. Abstr. 1998, 129, 587849.

13. Stevenson, C.; Davies, R.; Jeremy, H. Photosensitization of guanine-specific DNA damage by 2-phenylbenzimidazole and the sunscreen agent 2-phenylbenzimidazole-5-sulfonic acid. Chem. Toxicol. 1999, 12, 38-45.

14. Bai, Y.; Lu, J.; Shi, Z.; Yang, B. Synthesis of 2,15-hexadecanedione as a precursor of Muscone. Synth. Lett. 2001, 2001, 544-546.

15. Roth, M.; Norning Star, M.L.; Boyer, P.L.; Hughes, S.H.; Bukheit, R.W.; Miechejdu, C.S. Synthesis and biological activity of novel nonnucleoside inhibitors of HIV-1 reverse transcriptase. 2-Aryl-substituted benzimidazoles. J. Med. Chem. 1997, 40, 4199-4207.

16. Migawa, M.T.; Giradet, J.L.; Walker, J.A.; Roszalka, G.W.; Chamberlain, S.D.; Dracin, J.C.; Townsend, L.B. Design, synthesis, and antiviral activity of $\alpha$-nucleosides: d- and 1isomers of lyxofuranosyl- and (5-deoxylyxofuranosyl)benzimidazoles. J. Med. Chem. 1998, 41, 1242-1251.

17. Tamm, I.; Seghal, P.B. Halobenzimidazole ribosides and RNA synthesis of cells and viruses. Adv. Virus. Res. 1978, 22, 187-258.

18. Tamm, I. Ribonucleic acid synthesis and influenza virus multiplication. Science 1957, 126, 1235-1236.

19. Porcari, A.R.; Devivar, R.V.; Kueera, L.S.; Drach, J.C.; Townsend, L.B. Design, synthesis, and antiviral evaluations of 1-(substituted benzyl)-2-substituted-5,6-dichlorobenzimidazoles as nonnucleoside analogues of 2,5,6-trichloro-1-( $\beta$-d-ribofuranosyl)benzimidazole. J. Med. Chem. 1998, 41, 1252-1262. 
20. Pan, B.; Lu, X.Y.; Du, H.; Gao, M.I.; Huang, J.; Bao, X.P. Synthesis and biological activities of novel quinazolinone derivatives containing a 1,2,4-triazolylthioether moiety. Chem. Papers 2016, 70, 983-993.

21. Michaela, M.; Valeriu, S.; Lenuta, P.; Marcel, P.; Jacques, D.; Christian, P. Synthesis and biological activity of some new 1,3,4-thiadiazole and 1,2,4-triazole compounds containing a phenylalanine moiety. Molecules 2009, 14, 2621.

22. Mcclure, K.F.; Abramou, Y.A.; Laird, E.R.; Barberia, J.T.; Cai, W.; Carty, T.S.; Cortina, S.R.; Danley, D.E.; Dipesa, A.S.; Donahue, K.M.; Dombroski, M.A.; Elliott, N.C.; Gabel, C.A.; Han, S.; Hynes, T.R.; Lemottle, P.K.; Mansour, M.N.; Marr, E.S.; Letavic, M.A.; Pandit, J.; Ripin, D.B.; Sweeney, F.J.; Tan, D.; Tao, O. Theoretical and experimental design of atypical kinase inhibitors: Application to p38 MAP kinase. J. Med. Chem. 2005, 48, 5728-5737.

23. Trivedi, R.; De, S.K.; Gibbs, R.A. A convenient one-pot synthesis of 2-substituted benzimidazoles. J. Mol. Catalysis Chem. 2006, 245, 8-11.

24. Mcbride, C.M.; Renhowe, P.A.; Heise, C.; Jansen, J.M.; Lapointe, G.; Ma, S.; Pineda, R.; Vara, J.; Wiesmann, M.; Shafer, C.M. Design and structure-activity relationship of 3benzimidazol-2-yl- $1 \mathrm{H}$-indazoles as inhibitors of receptor tyrosine kinases. Bioorg. Med. Chem. Lett. 2006, 16, 3595-3599.

25. Sandhi, S.M.; Singh, N.; Kumar, A.; Lozack, O.; Meijer, L. Synthesis, anti-inflammatory, analgesic and kinase (CDK-1, CDK-5 and GSK-3) inhibition activity evaluation of benzimidazole/benzoxazole derivatives and some Schiff's bases. Bioorg. Med. Chem. 2006, 14, 3758-3765.

26. Salehi, P.; Dabiri, M.; Zolfigol, M.A.; Otokesh, S.; Baghbqanzadeh, M. Selective synthesis of 2-aryl-1-arylmethyl-1H-1,3-benzimidazoles in water at ambient temperature. Tetrahedron Lett. 2006, 47, 2557-2560.

27. Pandey, V.K.; Upadhyay, M.; Vpadhyay, M.; Gupta, V.D.; Tandron, M. Benzimidazolyl quinolinyl mercaptotriazoles as potential antimicrobial and antiviral agents. Acta Pharm. 2005, 55, 47-56.

28. Fahmy, H.T.Y.; Rostom, S.A.F.; Bekhit, A.A. Synthesis and antitumor evaluation of new polysubstituted thiazole and derived thiazolo[4, 5-d]pyrimidine systems. Arch. Pharm. Pharm. Med. Chem. 2002, 335, 213-222. 